\title{
Teaching pop vocal performance to students: A comparison of methods used in Russia
}

\author{
Natalia Ivanovna Anufrieva ${ }^{1}$ \\ Semyon Vyacheslavovich Limanov ${ }^{2}$ \\ Yana Mamonova ${ }^{1}$ \\ Natalia Vladimirovna Anchutina ${ }^{1}$ \\ Maria Lvovna Kats ${ }^{1}$ \\ ${ }^{1}$ Russian State Social University, Moscow, Russia \\ ${ }^{2}$ Moscow Provincial College of Arts, Moscow, Russia \\ DOI 10.12975/rastmd.2021924 Submitted July 15, 2021 Accepted Sept 26, 2021
}

\begin{abstract}
The present study aims to compare modern Russian and foreign methods of teaching pop vocal to college and university students from the point of their effectiveness and educational results based on the analysis of the theoretical background and experimental studies. Globalization, internationalization of cultures, the active introduction of electronic educational environments, and distance and online learning now allow mastering many vocal techniques and teaching methods and putting them into practice in a short amount of time. In this regard, the need to compare and evaluate modern Russian and foreign methods of teaching pop vocals, as well as identify the advantages and determine the prospects for their further use in pedagogical practice become relevant. The study summarizes the experience of teaching pop vocals and a comparative analysis of three modern methods of teaching - one foreign (Joe Estill) and two Russian (M.L. Kats and O. Donskaia). The results of the experiment show that the effectiveness of these techniques is due to the emphasis placed on the active and comprehensive development of the vocal apparatus, singing support, rhythmic coordination, singing vibrato, vocal techniques, melismatics, and the development of the vocal range and voicing resonators. The control stage of the experiment reveals the expressiveness of singing, the integrity of vocal pieces, the density of sound in all registers, and the improvement of the quality of timbral coloration of the voice in the tested group of students. These results were undoubtedly promoted by the previously studied and newly implemented methods of teaching pop vocals.
\end{abstract}

\section{Keywords}

pop vocal, teaching method, joe estill vocal school, maria kats vocal teaching method, olga donskaia vocal school

\section{Introduction}

At the turn of the 20th and 21st centuries, pop singing as a form of professional vocal art combining the folk song traditions, modern music, freedom of rhythm, and expressive arrangement of the work became especially popular among young people (Pereverzeva, 2017). The bel canto style that used to be of great importance in academic singing has faded into the background; the emphasis was put on the individual, their unique manner of performance, speech intonation, the ability to convey the meaning of the written text, and the expressive embodiment of the stage image.

Fundamental classical vocal schools serve as a strong foundation that has 
stood the test of time. However, it is the pop vocal that is one of the most popular areas of training in faculties of culture and art all over the world today. This is due to the development of pop culture in general and the mass popularization of this art form (Pereverzeva et al., 2018). Pop vocal is a relatively new type of special vocal technique. Summarizing the research devoted to the differences between pop and other vocal techniques, the following can be distinguished:

- The basic concept of pop singing is direct emotional communication with the listener, the freedom and openness of artistic expression of feelings.

- Diction, proper work of the articulatory apparatus, and support for breathing are extremely important.

- Mannerisms, incorrect word stress or deliberate stretching of sonorous consonants, imitation of wind instruments, and jazz scat are allowed.

The modern system of vocal training is changing rapidly, and the time frame is increasingly narrowed which calls modern music school and college graduates to maximize their knowledge and skills in a short period of time. Requirements for the training of specialists in various fields of pop culture and art are increasing. There are also growing requirements for teachers who use methods that have proven to be effective or develop their own methods of pop vocal training (Polotskaia, 2016).

\section{Literature review}

The methodological foundation of the study is formed by scientific-pedagogical and psychological research and met- hodical developments in the sphere of pop vocals including vocal pedagogics, the overall method of musical education, the methods of teaching the technology and aesthetics of pop vocals, voice training, the formation of vocal-performance skills, and vocal performance art.

I.O. Isaeva's work (Isaeva, 2017) contains the historical aspects of the emergence of variety art and refers to outstanding actors and singers, much attention is paid to diction, rhythm, articulation exercises, and the use of sound equipment in practical lessons.

The method of singing in the vocal position developed by Seth Riggs (Solianinova, Demidova, 2019) allows vocalists practicing both pop and academic vocals to control their voices automatically without obvious clamps. This technique can be used at any age without the risk of damaging the vocal apparatus. Diaphragm and oblique abdominal muscles supply the right amount of air, and the vocal cords work properly freely. The uniqueness of this method also lies in the possibility of doing the exercises on one's own without a vocal teacher by listening to a recording of the textbook.

Among the Russian vocal methodologies, we can highlight such authors as O.L. Donskaia-Anisimova (2019), V.V. Emelianov (2000), M.L. Kats (2018), V.I. Korobka (1989), E.P. Kuznetsova (2017), O.V. Pivnitskaia (2014), F.L. Polotskaia (2016), A.M. Pronin (2012) E.A. Sibirenko (2019), and E. Howard (2007). The authors point out that the methods of teaching the pop vocal technique vary from student to student and filtering out the ideal vocal instrument sound 
takes years. Unlike academic vocals that always use live orchestral instruments, pop music increasingly involves completely electronic sounds which, in turn, requires the vocalist to have good physical, intonation, and vocal training. "Pronunciation, diction and singing "in a mask", while smiling are the most important expressive means in the presentation of song material", - indicates E.P. Kuznetsova (2017, p. 189). This is fully supported by other Russian developments of pop vocal training among which we can allocate the works of $\mathrm{V}$. I. Korobka (1989) and O.S. Chernova (2014) providing detailed descriptions of complexes of exercises for the development of students' singing apparatus, abdominal rib-diaphragmatic breathing, and sound phrasing in the pop technique of singing.

\section{F. L. Polotskaia (2016) indicates that}

"Vocal pedagogics is a subject that is constantly improving and developing, there are new methods of discovering and forming the voice. This is due to the fact that pop singing finds great importance in the individuality, artistry, and recognizability of the voice from the first notes of the sound" (p. 432).

The teacher needs to form, find, and develop these qualities in students, as well as to be able to analyze the complex nature of educational and pedagogical technologies in general. Based on the analysis of Russian and foreign methods of pop vocal training that are already known and studied in detail in this work, we can state that each of them sets certain learning objectives and influences the further development and discoveries in pop vocal training in music colleges.

\section{Problem of Study}

In this study, it is aimed to compare the methods used in pop voice education. According to this, the methods used in vocal education in Russia and the modern vocal training system are changing rapidly. The time frame for student education is narrowing, requiring today's graduates of music schools and colleges to receive maximum knowledge and skilIs in a short time. In addition, over the past 1.5 years, there has been a forced need to participate more in distance learning. This requires teachers to improve the teaching methodology while students need to make more volitional efforts to strive for personal self-development and adapt to distance learning conditions.

\section{Methods}

\section{Research Model}

This research was designed according to the comparison method, one of the qualitative research methods (Estill Voice International, n.d.; Katz, 2018; Donskaia-Anisimova, 2019). Accordingly, 3 methods used in pop vocal (The Estill Voice Training International Academy School, The methods of Maria Lvovna Kats, The method of Olga Anatolievna Donskaia) in Russia were compared according to practices, observations, experiences and research results.

\section{Comparison Units (Methods of} teaching pop vocal)

Within the framework of the study, we summarized the experience of teaching pop vocals and conducted a comparative analysis of three modern training 
methods - one foreign and two Russian:

The Estill Voice Training International Academy School (by Joe Estill) which has produced over a million vocal masters and coaches worldwide and has its own unique and patented methodology for teaching vocal technique (Estill Voice International, n.d.);

The methods of Maria Lvovna Kats (2018) developed in the process of professional concert activities and applied in pedagogical practice in the Russian State University of Social Sciences, as well as during the training and education of actors of the Mossovet Theater, the Russian Institute of Theater Arts, Moscow Art Theater, Gogol Center, the Theater of Nations including Alexander Domogarov, Ksenia Rappoport, Paulina Andreeva, Nadezhda Angarskaia, Anastasia Stotskaia, Ekaterina Guseva, Natalia Gromushkina, and many others;

The method of Olga Anatolievna Donskaia representing the Russian school of pop vocal "Freedom and Will", professor of the Department of Pop and Jazz Singing of the Moscow State Art and Cultural University, an associate professor of directing and acting at the Russian Academy of Theater Arts (the Moscow State Art and Cultural University), the author of a unique vocal technique whose graduates are win and participate in many prestigious international competitions and television projects (Kirill Koroviakov, Aurika Mgoi, Alexander Peskov, Julia Khusainova, and many others) (Donskaia-Anisimova, 2019).

\section{Results}

Scientifical Aspects of Methods

All three methods emphasize active and comprehensive development of the voice apparatus, singing support, rhythmic coordination, singing vibrato, vocal techniques, melismatics, and the development of the vocal range and voicing resonators. Each school has its own vocal developments derived from practical pedagogical and concert practice, continuous self-improvement, and extensively studied scientific works on vocal art. Each vocal methodology is unique in its discoveries and refined ways of presenting information to students which results in a powerful dynamic in the development of the vocal apparatus and the creative potential of the experimental group (Howard, 2007).

Vocal schools of the three modern methods of pop vocal teaching were studied in the course of practical pedagogical work to identify their advantages, the specifics of the technologies, and the prospects for the implementation of these scientific developments in the educational process (Pereverzeva, Smirnov, 2017).

At the present moment, there is only one scientific method - Estill Voice Training (Voice Craft) that has been practiced in virtually all European countries since the 1980s and was first introduced in Russia in 2015. All propositions of the method are based on and supported by scientific research. A list of scientific papers, publications, and videos can be found on the website of Estill Voice International, an association that organizes worldwide research and training. The effectiveness and safety of the exercises are also scientifically verified (Pronin, 2012).

The uniqueness of this method lies in 
the confirmed scientific developments and laboratory research revealing the anatomy of the vocal cords, larynx, cartilage, demonstrating it in video recordings, and describing it at seminars. Joe Estill's main discovery in the development of the EVT method is the notion of belting as a separate manner of vocal performance very similar to dense mixed singing in which the sound in the second octave in female voices is heard from the outside as a very dense resonator-like chest sound. Breathing remains short and practically without air, there are variants with the addition of nasal, covered sounding. There are some similarities with folk and conversational singing, the main distinguishing feature is the slightly or highly forced sound that comes, however, from the resonators, so there are almost no loud volume drops in the professional sound (Estill Voice International, n.d.).

The second discovery is the speech position, or singing in a conversational position (Seth Riggs), a prominent representative of this vocal technique is Frank Sinatra who skillfully sang in this manner without any microphones easily performing in large venues (Pereverzeva, 2019). These methods of sound extraction can be combined with other methods, for example, subtone or nasal twang (Italian singer Eros Ramazzotti) in vocal phrases that make up a musical work, thus obtaining the variety manner of singing the distinctive feature of which are various and multi-genre vocal methods of sound extraction. These techniques have been easily mastered and successfully applied in the training of pop-jazz vocalists (Budnitskaia, 2012).

It should be noted that EVT pays little attention to singing support in contrast to the detailed and well-developed exercises in our method or the method of O.A. Donskaia. There is a concept of anchoring (from anchor) - these are two points of certain "tension" in the back of the wings of the back and the cervical spine in a dynamically voluminous extraction of sound in opera or belting genre.

M.L. Katz was trained in Speech Level Singing personally by Seth Riggs, and her vocal methodology is based on his teachings. Speech Level Singing allows for vocal training at any age, makes it possible to expand the singing range in a short time, and allows to control the vocal apparatus freely. My book touches on the problem of developing the met-rhythm that is necessary for every singer, especially those working with live bands, and has paramount importance in performing jazz music. Much of improvisational music originates from Africa, the most important sources being African American blues and gospel (Pereverzeva, 2019). Improvisational music requires special attention to complex warm-ups for the expansion of the singing range with a detailed singing of the intervals of stable-unstable steps in different forms with gradually increasing tempo (Pereverzeva \& Smirnov, 2017).

M.L. Kats recommends regular exercise on elliptical trainers or doing singing warm-up exercises on a balancing disc. In the process, the brain activity is simultaneously focused on several activities - vocalization, breathing, and physical work on balancing the body on the training apparatus. At this point, vocal and muscle clamps disappear because of the multidimensional tasks performed by the brain and neural networks, mo- 
reover, there is physical training for the whole body, and the focus is constantly switching which prevents dwelling on the problem areas.

O. A. Donskaia's methodological developments analyze the psychophysical processes during singing in the "singing mask" and the correct use of nasal resonation. In her recommendations, the larynx remains very mobile, and the root of the tongue is to be lowered down. This technique makes it very easy to use the belting technique from the EVT. Donskaia's technique makes it easy to understand the principle of jazz square phrases (Donskaia-Anisimova, 2019).

Thus, it becomes easy to swing and not drag out vocal phrases. It should be noted that all three vocal techniques are unique and provide many opportunities to master the vocal apparatus in completely different genres of vocal art such as opera and musical Broadway, jazz and alternative rock, electronic music, and urban romance which is an absolute priority in learning pop vocals (Shafazhinskaya et al., 2019).

\section{Assessment of the effectiveness of training}

The results of students' training were evaluated in practical pedagogical work in a college through practical exercises, vocal figures, breathing exercises, and work on the song repertoire with and without an accompanist. During the experiment, at the end of each month, the students were gathered in groups for general question-and-answer lessons on the knowledge of vocal terms, the structure of the vocal apparatus, the proper functioning of the singing support, and a discussion of the manner and techniques of sound production by famous Russian and foreign performers.

The duration of each of the individual lessons was 45 minutes and the combination of methodological principles involved in them was as follows: Warming up facial muscles and the cervical spine, twisting, exercises for breathing, diaphragm, and pelvic floor muscles, articulation exercises, tongue twisters, Moran's point, working through the main resonators in warm-up chants, exercises on smoothing the registers, interval chants, relieving muscle clamps, the exercise of different ways of sound production in one vocal phrase, a detailed step by step analysis of the selected song, the elimination of phonetic, melodic, and articulation errors, singing the song material with the metronome, work with the accompanist.

\section{Examples of exercises used}

Below we present some examples of exercises that have shown to be effective in training pop vocalists.

Exercise 1. Melisms, emphasis on the rapidity of singing, accurate intonation on the jotated eye sounds. A minimal amount of air is consumed in the performance (from the author's manual).

Exercise 2. Building up even vowel sounds, interval intonation. Smoothing transitional registers (from the author's manual).

Exercise 3. Tongue twister with the supporting letter "l": "Karl u Klary ukral korally, a Klara u Karla ukrala klarnet" (Russian). The supporting sounds should not fall through but be pushed to the bridge of the nose, this requires voicing 
the vowel "a". In this case, all the sonorous sounds will become clear (from the manual of O. L. Donskaia).

Exercise 4. For relaxation and even breathing before the main singing of the figures. Four short inhales and exhales, then one long inhale and a long exhale immediately after. The exercise is to be performed at a quiet pace with silent inhalation and exhalation through the nose (from the complex of EVT exercises).

Exercise 5. Tongue twister exercise: "Sshit kolpak ne po-kolpakovski. Nado kolpak perekolpakovat da perevykolpovat" (Russian). The exercise strengthens the low position. The student has to fold their hands in front of them, on their belly, and imagine that the whole exercise is voiced in the direction of this spot or that the top note that goes to the octave down should sound to them exactly one octave lower. For this purpose, the point of the lower jaw is used. The student has to stay in the same position. On the top note, the jaw is pulled down, brought slightly forward, attention is paid to the vowel " $\mathrm{i}$ " - it is necessary to avoid letting the " $y$ " vowel mark the lower note in the high position through the " $n$ " sound.

In the process of working on singing warm-ups and perfecting individual phrases, the experiment participants were tasked with approaching the "boring" exercises and monotonous repetitions of the same repetitive vocal figures creatively through imagining it to be a fragment of a musical piece. The students were suggested to take a phrase from a famous song and sing it using different vocal techniques, for instance, a 3-word phrase from the famous song "All by myself" (sing the 1st word in a belting manner, sing the 2 nd word in a subtone, and finish the 3rd word with belting). The sounds had to then be combined into a single vocal phrase followed by swapping the places of the techniques. The developed skill was then applied in solo songs using a dynamic microphone.

\section{Discussion}

The experimental study of the effectiveness of Russian and foreign methods of pop vocal training was conducted at the Moscow College of Improvisational Music (MCIM) in Moscow that graduates professional jazz musicians. The period of study varies depending on the level of knowledge and training of the students (4-5 years). The experiment sample consists of 18 students of the preparatory and 1 st year of the vocal department at the age of $18-30$ years old. The study began in September of 2020 and the conclusion and result summarization took place in the middle of January of 2021. Experimental and experimental work included 2 control stages:

- intermediate;

- final.

The experimental group of 18 trainees was divided into 10 students of the $1 \mathrm{st}$ year and 8 students of the 2 nd year of the vocal department of the MCIM.

Further on, students with a high level of training (initial vocal data, musicality, and theoretical background), average level of training (problematic transitional notes, unstable vocal support), and below the average level (no training in a children's music school) were identified in the sample (see Figure 1). 


\section{Levels of students' training}

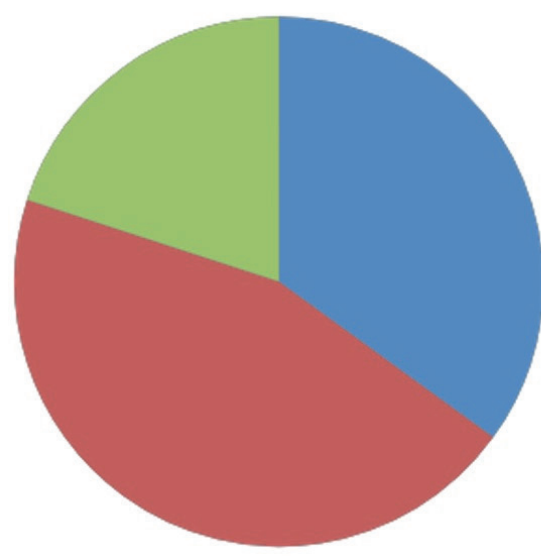

High level of training

Average level of training

Low level of training
Figure 1. Levels of training in the participants of the experimental group (18 people). The control group was taking individual 45 minute long lessons once a week for half a year. Students of the 1st year (10 persons) were simultaneously training in two vocal schools of Maria Lvovna Kats and Olga Leonidovna Donskaia. Students of the 2 nd year ( 8 people) were studying by the EVT program
The diagnostic stage was based on students' ability to create and possess:

- stage image, artistry;

- psychological stability at open lessons and concerts;

- skills of abdominal breathing during singing support;

- practical knowledge of nominal chants and vocalizations.

Diagnostics during the experimental study were based on practical exercises and tasks from M.L. Kats', O.A. Donskaia's, and the EVT methods (see Figure 2). The experimental group of students generally showed good results, however, in the process of training by modern methods, problems with associative thinking (interpretation of works) and comprehension of new material (comprehension of information) were observed, some students demonstrated inattention in the classroom and, consequently, showed poor recollection of the presented information(tolerance of perception).

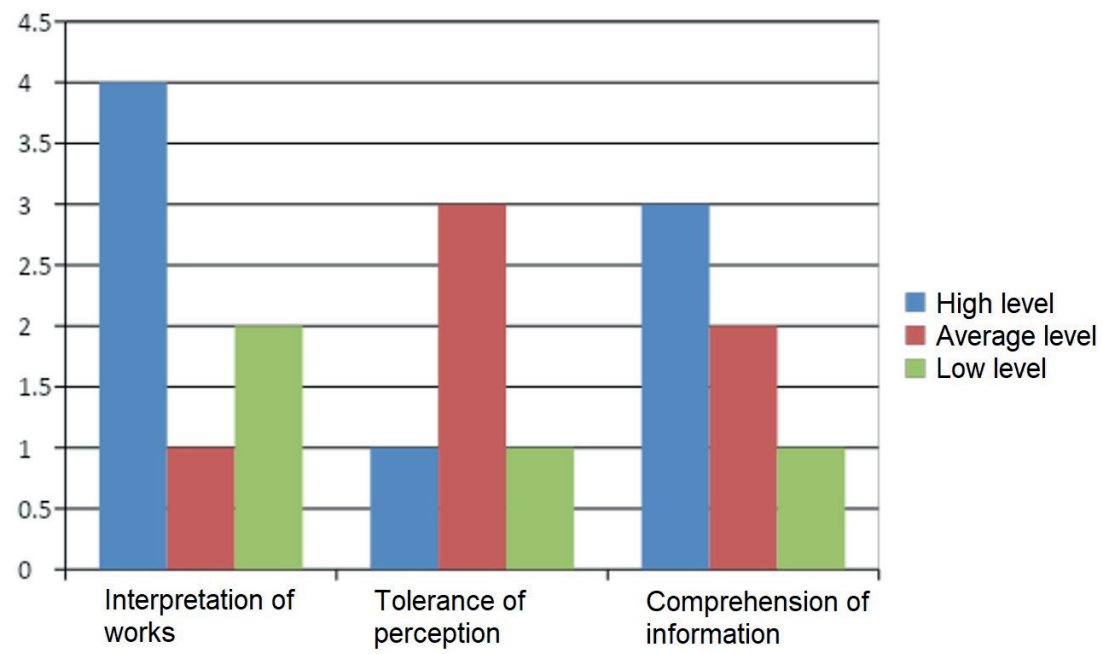

Figure 2. The results of diagnostics on practical exercises and tasks in the experimental group 
The intermediate stage of experimental work shows that in all three methods of teaching pop vocals, singing in the speech position is introduced into practical classes gradually and depends on the initial degree of students' preparation. The overall scores of 9 students corresponded to a high level (5 points),
6 students were at the average level ( 3 points), and the remaining 3 students had a low level (one point each) (see Figure 3). Difficulties arose in learning tongue twisters, memorizing vocal figures by the EVT method, and memorizing the structure of the song material.

\section{Levels of students' training}

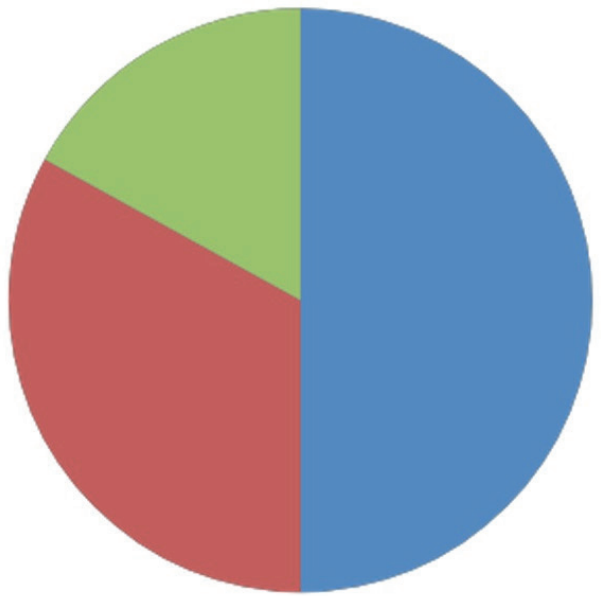

High level of training

Average level of training

Low level of training

Figure 3. Levels of training in the experimental group participants after the experiment (18 people)

A comparative analysis of the initial and final stages shows clear dynamics in the process of receiving training according to these methods, as well as personal professional growth. Thus, the main objective of forming students' vocal awareness in terms of the practical application of modern methods of pop vocal training was fulfilled.

As a result of the experimental work with a group of students in the educational process, many of those who previously had little vocal experience and improvisation skills have gained these qualities along with creative interest and confidence in their vocal abilities through a strong-willed effort and desire for personal self-development. The control stage of the experiment reveals expressiveness of singing, the integrity of vocal pieces, the density of sound in all registers, and improved quality of timbral coloration of the voice in the tested group of students. This improvement was undoubtedly promoted by the use of the previously studied and newly implemented methods of teaching pop vocals.

\section{Conclusion}

The analysis of the existing psychophysical and methodological features of vocal training for college students leads to the conclusion that the teacher needs to be well versed and apply proven methods of vocal training. Modern pop vocal teachers pay much attention to the psycho-physical features of sound extraction, as well as teaching the ba- 
sics of sound extraction, the method of resonance singing, compliance with voice hygiene, the development of the respiratory apparatus, and the acquisition of singing support. This ensures professional voice production and the mastery of singing skills and abilities.

Modern methods of vocal training stress the importance of the participation of certain muscle groups in setting the correct vocal breathing. For example, according to the Estill Voice Training method and M.L. Kats' methodology, the development of proper vocal breathing also requires training neck and upper back muscles, it is important to follow the correct posture, try to sing while moving or on a treadmill. The student must know and be able to timely diagnose colds, therefore, they have to be familiar with their main symptoms.

\section{Recommendations}

The results of the work will be used in further studies of modern methods for teaching pop vocal, including the method of S. Riggs and I. Sokerina, the advantages of which can be determined by comparing specific learning outcomes. In the future, it makes sense to evaluate the effectiveness of these methods when teaching students with the same initial level of training, as well as teaching beginner students. Further research might also concern the question of the influence of training according to one method or another on the artist's creative career. It would be interesting to trace which pop singers achieve higher artistic results - those who were trained according to the method of Estill, M.L. Katz, or O.L. Donskaya?

The present study is limited by all three of the aforementioned techniques being implemented and compared in the context of training pop college students. The study results can be implemented in assessing the effectiveness of the use of techniques for training pop singers in universities based on experimental work. The theoretical value of the work consists in a comparative analysis of the most popular methods of training pop vocalists and the identification of their common grounds determining the effectiveness of their use in the educational process. The practical significance of the study lies in the formulation of methodological recommendations for the training of pop vocalists in college.

The limitations of the study were due to the subjectivity of the criteria for assessing learning outcomes. Since the artistic aspect is not parameterizable, that is, it cannot be measured or calculated, the assessment is based on the emotional impressions of singing. It is advisable to develop more objective criteria or refer to the assessment of the parameters of pop singing with the help of technical means - computer programs for the analysis of sound information.

Acknowledgement: none

Conflict of interest: none 


\section{Biodata of Authors}

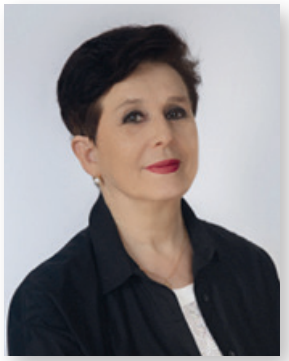

Natalia Ivanovna Anufrieva, Dr.

Interest of author: Theory and history of folk art culture and ethno-art education, technologies and methods of music education, Music performing arts, Management in cultural, art and educational institutions, Music performing schools and concepts, Theory, methodology and organization of social and cultural activities, Pedagogy of folk art creativity, Innovative musical and pedagogical technologies. Affiliation: Russian State Social University, Moscow, Russia Email: nata415485@mail.ru ORCID: https://orcid.org/00000003-4119-9805 SCOPUS id: https://www.scopus.com/authid/detail.uri?au thorld=56584402900 Elibrary: https: / /elibrary.ru/author_items.asp?authorid=261417

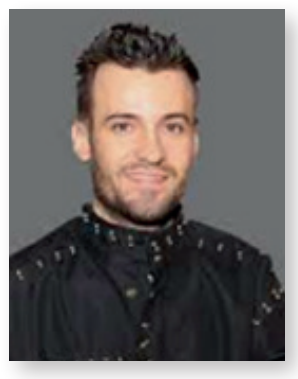

\section{Semyon Vyacheslavovich Limanov}

Interest of author: Theory and methodology of teaching pop vocal. Affiliation: Moscow Provincial College of Arts, Moscow, Russia Email: limanov_s@mail.ru ORCID: https://orcid.org/0000-0001-6027-9769 Elibrary:https://www.elibrary.ru/item. asp?id=43290199

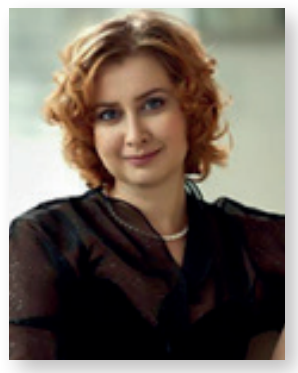

\section{Yana Mamonova}

Interest of author: Professional training of a vocalist in a modern university, theory and methodology of vocal art. Affiliation: Russian State Social University, Moscow, Russia Email: ya.a.mamonova@mail.ru ORCID: https://orcid.org/0000-0002-9427-9326

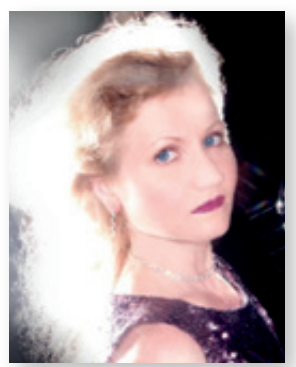

\section{Natalia Vladimirovna Anchutina}

Interest of author: Participation in regional and international conferences, in the jury of music competitions, publications in Russian and international magazines; Work as an associate professor of the Department of Stringed Folk Instruments at the Gnessin Russian Academy of Music; Areas of scientific activity: Socio-cultural activities, methods of music education, innovative technologies in music, education, pedagogy of performing arts. Affiliation: Russian State Social University, Moscow, Russia Email: anchutinanatalia@mail.ru ORCID: https:// orcid.org/0000-0002-1282-6147 SCOPUS id: https://www.scopus.com/authid/detail. uri?authorld $=57216282681$ 


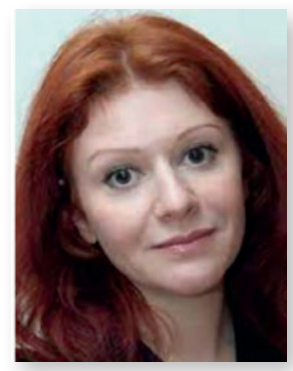

\section{Maria Lvovna Kats}

Interest of author: Participation in regional and international conferences, congresses. Social, psychological, pedagogical and technical conditions for the acquisition of professional skills of a modern vocalist in the digital educational environment of the university; Variety performer professional training; Theory and methods of teaching pop vocal. Affiliation: Russian State Social University, Moscow, Russia Email: mkatz@mail.ru ORCID: https: / / orcid.org/0000-0001-7014-6476 SCOPUS id: https: / /www.scopus. com/authid/detail.uri?authorld=57201883397 Elibrary: https: / /www.elib rary.ru/author_items.asp? authorid=958559 


\section{References}

Budnitskaia, T.A. (2012). Istoriia stanovleniia professionalnogo dzhazovogo obrazovaniia $\vee$ Rossii i SShA: sravnitelnyi analiz [The history of the development of professional jazz education in Russia and the USA: a comparative analysis]. Vestnik Moskovskogo Gosudarstvennogo Oblastnogo Universiteta. Seriya: Pedagogika, 2, 5-10.

Chernova, O.S. (2014). Podgotovka nachinaiushchego estradnogo vokalista $k$ kontsertno-ispolnitelskoi deiatelnosti [Preparation of a novice pop vocalist for concert performance]. Pedagogicheskoye obrazovaniye $v$ Rossii, 12, 227-231.

Donskaia-Anisimova, O.A. (2019). Svoboda i volia. Russkaia shkola estradnogo vokala: uchebno-metodicheskoe posobie [Freedom and will. Russian school of pop vocal: teaching aid]. Moscow: n.p., $190 \mathrm{p}$.

Emelianov, V.V. (2000). Razvitie vokalnoi metodiki [Development of vocal techniques]. Saint Petersburg: Lan, 190 p.

Estill Voice International. (n.d.). https: / / www.estillvoice.com/ (date of access: December 11, 2020).

Howard, E. (2007). Tekhnika peniia. Vokal dlia vsekh [Singing technique. Vocals for everyone]. Moscow: Smolin K.O., 62 p.

Isaeva, I.O. (2017). Estradnoe penie. Ekspress-kurs razvitiia vokalnykh sposobnostei [Pop vocals. An express course of the development of vocal abilities]. Moscow: Astrel, $318 \mathrm{p}$.
Kats, M.L. (2018). Vash golos: sekrety vokalnogo masterstva [Your voice: secrets of vocal mastery]. Moscow: Alpina Publisher, $192 \mathrm{p}$.

Korobka, V.I. (1989). Vokal v populiarnoi muzyke: metodicheskoe posobie [Vocals in popular music: a methodical guide]. Moscow: Studiia Rekord, 46 p.

Kuznetsova, E.P. (2017). Metodologicheskie razlichiia trebovanii $k$ podgotovke akademicheskikh i estradnykh vokalistov [Methodological differences in the requirements for the training of academic and pop vocalists]. Istoricheskie, filosofskie, politicheskie nauki, kulturologiia $\mathrm{i}$ iskusstvovedenie. Voprosy teorii i praktiki, 9(83), 188-121.

Pereverzeva, M.V. (2017). Traditsionnaia muzyka SShA: istoricheskaia i zhanrovaia panorama [Traditional music in USA: historical and genre panorama]. Muzykalnaia akademiia, 2(758), 89-95.

Pereverzeva, M.V. (2019). Angloamerikanskii folklor: ot kovboiskoi ballady k stiliu kantri [Anglo-American folklore: from cowboy ballad to country style]. In: I.A. Korsakova (Ed.), Artistic space of culture of the third millennium: problems of science and education. Collection of scientific works of the Schnittke Higher School of Music (Institute) of the Russian State Social University (pp. 179209). Moscow: Russian State Social University.

Pereverzeva, M.V., Smirnov, A.V. (2017). Sovremennoe solfedzhio kak uslovie formirovaniia professionalnykh kompetentsii uchitelei muzyki [Modern solfeggio as a condition for the formation of professional competencies in music teachers]. 
Scientific Notes of the Russian State Social University, 16(5(144)), 159-167.

Pereverzeva, M., Anufrieva, N., Shcherbakova, A., Anufriev, E. (2018). USA music as a reflection of the national sociocultural values. In: A. Maloletko, N. Rupcic, Z. Baracskai (Eds.), Economic and Social Development. Book of Proceedings (pp. 840-846). Varazhdin: Varazdin development and entrepreneurship agency.

Pivnitskaia, O.V. (2014). Osobennosti intonirovaniia $v$ sovremennom estradnom vokale: istoricheskii i pedagogicheskii aspekty [Features of intonation in modern pop vocal: historical and pedagogical aspects]. Muzykalnoe iskusstvo i obrazovanie, 3, 127-133.

Polotskaia, F.L. (2016). Nekotorye aspekty vokalno-pedagogicheskogo vospitaniia pevtsov $v$ estradnom vokalnom ansamble [Some aspects of vocal pedagogical upbringing of singers in a pop vocal ensemble]. Aktualnye problemy prava, ekonomiki i upravleniia, 12, 430434.

Pronin, A.M. (2012). Metodika razvitiia proprioritseptsii dykhatelnogo apparata $v$ protsesse obucheniia estradnomu vokalu [Method for the development of proprioception of the respiratory apparatus in the process of teaching pop vocal]. Vestnik TGU, 10(114), 241-246.

Shafazhinskaya, N.E., Shcherbinina, V.M., Ivanova, E.Y., Belyakova, T.E., Pereverzeva, M.V. (2019). Learning about world art culture as a method of forming a universal cross-cultural communication competence. Humanities and Social Sciences Reviews, 7(6), 1225-1229.
Sibirenko, E.A. (2019). Razvitie vokalnykh navykov po metodike "COMPLETE VOCAL TECHNIQUE" [Development of vocal skills according to the "COMPLETE VOCAL TECHNIQUE" method]. Iskusstvo i obrazovanie, 4, 61-69.

Solianinova, L.K., Demidova, V.I. (2019). Ispolzovanie metodiki Seta Riggsa v protsesse obucheniia estradnomu vokalu [Using Seth Riggs' method in teaching pop vocal]. In: O.V. Gribkova (Ed.), Muzykal'noye obrazovaniye i nauka v sovremennom mire (pp. 302-307). Moscow: Pero. 